\title{
PVD-bevonatos forgácsolószerszámok adhéziós viselkedése
}

\section{Adhesion behavior of PVD-coated cutting tools}

\author{
Fábián Enikő Réka, ${ }^{1}$ Horváth Richárd ${ }^{2}$ \\ Óbudai Egyetem Bánki Donát Gépész és Biztonságtechnikai Mérnöki Kar. Budapest, Magyarország \\ ${ }^{1}$ fabian.reka@bgk.uni-obuda.hu \\ ${ }^{2}$ horvath.richard@bgk.uni-obuda.hu
}

\begin{abstract}
Cutting with TiAlN or CrAlN tip PVD coated tungsten-carbide based inserts, manufactured by powder metallurgy were found no significant difference in the wear comportment of inserts regardless of whether the insert worked in wet or dry conditions. The adhesion properties of coating layers on were studied by scratch test and by Daimler-Benz test. On the tungsten-based carbide cutting tool, the thinner TiAlN coating showed slightly better adhesion than the thicker CrAlN coating.
\end{abstract}

Keywords: TiAlN, CrAlN, adhesion test, Calo test.

\section{Összefoglalás}

TiAlN, illetve CrAlN típusú PVD-bevonattal ellátott, a volfrám karbid alapú, porkohászati úton gyártott keményfém lapkákkal való forgácsoláskor jelentős különbséget nem tapasztaltunk lapkák kopásánál, függetlenül attól, hogy nedves vagy száraz körülmények közt dolgozott-e a lapka. A bevonatok tapadási tulajdonságait karcteszttel, illetve Daimler-Benz-teszttel vizsgáltuk. A volfrám alapú keményfém lapkákon a vékonyabb TiAlN-bevonat valamivel jobb tapadást mutatott, mint a CrAlN-bevonat.

Kulcsszavak: TiAlN, CrAlN, tapadásvizsgálat, Calo-teszt.

\section{Bevezetés}

A forgácsolószerszámok, kivitelük, anyaguk, geometriai kialakításuk, rendeltetésük, alkalmazási feltételeik figyelembevételével különböző szempontok alapján több csoportba sorolhatók. Rendeltetés szerint megkülönböztetnek esztergáló-, fúró-, maró- stb. szerszámokat. A szerszámmal szemben támasztott főbb müszaki-gazdaságossági követelmények: a funkció minőségi ellátása, pontosság, magas élettartam, termelékenység, gazdaságosság. Ezeknek a követelményeknek a szerszám csak akkor tud megfelelni, ha a szükséges tulajdonságokkal rendelkezik. Ezek között döntő szerepe van az anyagtulajdonságoknak. A szerszámok tönkremenetelének főbb oka az abrazív és dinamikus igénybevételek során létrejövő kopás. A kopásállóság javítása érdekében a szerszámokat gyakran felületkezelik [1-5], illetve bevonatolják [6-9]. A bevonatok tulajdonságai függnek azok szerkezetétől, orientációjától, súrlódási együtthatójától, de az alapanyag hőkezeltségi állapotától is [10-11].

\section{Előzmények}

Szakirodalmi adatok szerint volfrámalapú keményfémen a TiAlN kopása kisebb, mint a CrAlN-bevonaté [10], ugyanakkor melegalakító szerszámacélokon jobb tapadásállóságot mutatnak a CrAlN-bevonatok, mint a TiAlN-bevonatok [11]. Forgácsolási tulajdonságok vizsgálataihoz öntött állapotú GX2CrNiMoCuN25-6-3-3 minőségű szuperduplex acélt ipari körülményeknek megfelelően forgácsoltuk 5 perces időtartamban. A forgácsolási sebesség: $v_{c}=70 \mathrm{~m} / \mathrm{min}$; előtolás: $f=0,175 \mathrm{~mm}$; fogásmélység: $a=1 \mathrm{~mm}$ volt. Azt tapasztaltuk, hogy függetlenül attól, hogy száraz 
vagy nedves körülmények között történt-e a forgácsolás, a két különböző PVD-bevonattal ellátott CNMG 120408 típusú lapka (nanokristályos TiAlN-, illetve nanokristályos CrAlN-bevonat) kopási képe jelentős eltérést nem mutatott, ahogy az 1. ábrán is látható. Kopás mindenik esetben fellépett.

Az 1. a) ábrán látható, hogy száraz forgácsoláskor a TiAlN-bevonatú szerszámon ép bevonat 5 perces forgácsolás után csak a fogásmélység „Zónáján” kívül található. Amikor kenőfolyadékot használtunk a forgácsoláskor a TiAlN-nel bevonatolt szerszámnál, nem alakult ki a homloklapon a forgácstörő horonyig élrátét, viszont a forgácstörő horonyról és annak közeléből az abrazív kopás miatt teljesen lekopott a bevonat (1. ábra b). Hasonlóan a szárazforgácsoláshoz, kenéses forgácsolási körülmények között is tapasztalható volt élkipattanás a főél mentén.

A CrAlN-bevonatú szerszámon száraz körülmények között nincs álforgács, illetve felrakódás a homlokfelület forgácstörő zónájában, viszont a forgács folyamatos koptató hatása teljesen lekoptatta a bevonatot (1. ábra c). Nedvesforgácsoláskor CrAlN-bevonatú szerszámon kipattanás nem található, de a duplex acélból nagy mennyiségü felrakódás található az él mentén. Ennél a szerszámnál a duplex acélból származó feltapadás megtalálható a homlokfelületen hosszan a forgácstörő zónában is (1. ábra d).

A vizsgálati eredmények kissé meglepőek voltak, mivel a forgalmazó szerint a CrAlN súrlódási

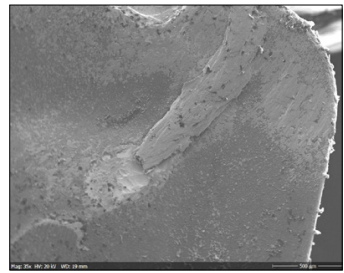

a)

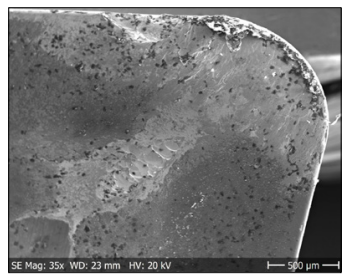

c)

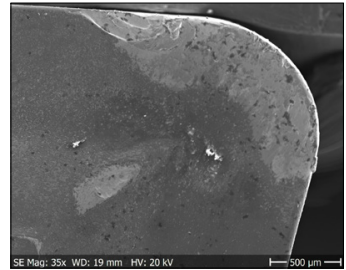

b)

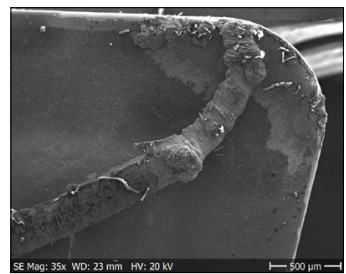

d)
1. ábra. Bevonatolt vágólapkák kopása. Élrátétképződés a) TiAlN-bevonat+ szárazforgácsolás

b) TiAlN-bevonat+ nedvesforgácsolás

c) CrAlN-bevonat+ szárazforgácsolás

d) CrAlN-bevonat+ nedvesforgácsolás együtthatója kisebb $(0,4)$, mint a TiAlN-bevonaté $(0,6)$; a TiAlN-bevonat keménysége 3200 HV, míg a CrAlN-bevonaté 3300 HV.

Annak kiderítése érdekében, hogy mi lehet ennek hátterében, különböző módszerekkel vizsgáltuk a szerszámokon a tényleges rétegvastagságot és a tapadásállóságot.

\section{Felhasznált anyagok, vizsgálati eljá- rások}

A porkohászati eljárással készült CNMG120408 típusú vágólapkák bevonatolása hagyományos ipari körülmények között történt. Mivel nemcsak a bevonati réteg, de a vágólapkák keménysége is igen nagy, a metallográfiai módszerekkel való rétegvastagság-mérés igen körülményes, a bevonati réteg jó eséllyel lepattanhat, még gyémánttárcsás vágással is. Az alapanyag keménysége a hagyományos metallográfiai csiszolást is igen nehézkessé teszi, ezért a rétegvastagság-méréshez Calo-tesztet használtunk [12-14] 30 mm-es átmérőjü koptató $\mathrm{Al}_{2} \mathrm{O}_{3}$ golyóval. Az eljárást a DIN EN 1072-2 szabvány rögzíti. A vizsgálat alapja a két felület között fellépő súrlódás okozta koptató hatás. A vizsgálat során egy edzett Ø30 mm-es golyó felületére abrazív szemcsetartalmú szuszpenziót viszünk fel, melyet dörzshajtással mozgásba hozunk, ami közben az nekitámaszkodik a mérendő felületnek.

Tapadásvizsgálathoz részben karctesztelést használtunk $\mathrm{MST}^{3}$ berendezéssel [15], részben a Daimler-Benz-tesztet alkalmaztuk [16].

\section{Vizsgálati eredmények}

A Calo-teszt alkalmazásakor a koptatógolyó forgása és az abrazív szuszpenzió hatására egy gömbsüveg formájú kráter keletkezik (2. ábra). A keletkezett kopást mikroszkóp alatt megmérjük, és matematikai úton kiszámítjuk a rétegvastagságokat [14].

A rétegvastagság $(\mathrm{T})$ a következőképp adódik:

$$
T=\frac{X \cdot Y}{D} ; \mu m
$$

A jelölések a 2. ábrából olvashatók le.

A bevonatolt keményfémlapkákon a különböző bevonati rétegek vastagságának különbsége jelentős (3. ábra).

A Calo-teszt után fénymikroszkópon lemérve a gömböveket határoló körök átmérőjét, a TAlN-réteg vastagsága átlagosan 6,2-7,4 $\mu \mathrm{m}$ közöttinek adódott, míg a CrAlN-réteg csak épp meghaladta a $3 \mu \mathrm{m}$-t (átlagosan 3,3 $\mu \mathrm{m}$ ). 
Az MST³-berendezéssel végzett karcolásos vizsgálatok eredményeit a 4 . ábra szemlélteti.

A vágólapkák karctesztelésekor a CrAlN-réteg lepattogzása már 4,03 N erőnél megindult (4. ábra), miközben a TiAlN-bevonatnál karakterisztikus lepattogzás nem következett be kis terheléskor, de még az eszköz által alkalmazható maximális $30 \mathrm{~N}$ terheléskor sem, ugyanakkor akusztikus jeleket már igen kis terheléskor is észlelni lehetett (4. ábra).

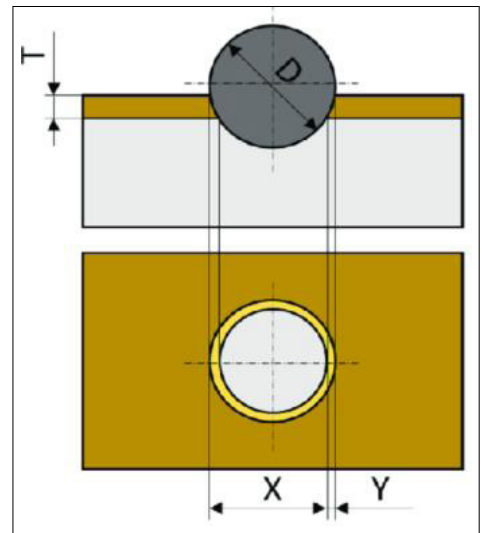

2. ábra. Jelölések rétegvastagság-számításhoz

a)

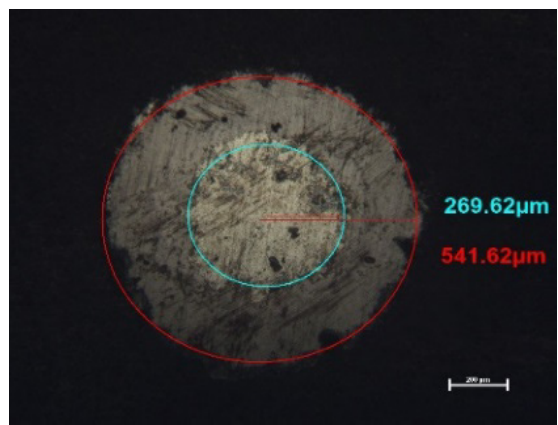

b)

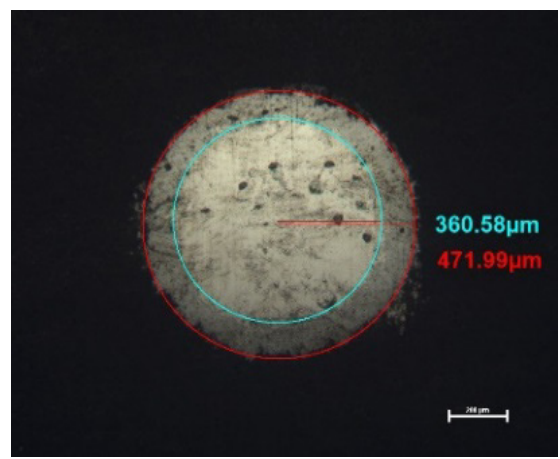

3. ábra. A CNMG120408 lapka bevonati rétegeinek fénymikroszkópos megjelenése Calo-teszt után, a) TiAlN-bevonat b) CrAlN-bevonat
A Daimler-Benz-teszthez Rockwell-keménységmérőt alkalmazunk gyémántkúp behatolótesttel és $1470 \mathrm{~N}$-os terheléssel.

A lenyomatok optikai mikroszkóp segítségével HF1-től HF6-ig terjedő besorolásra kerültek a VDI 3198 szerint [16]. A CNMG 120408 vágólapkáknál a PVD-technikával felvitt CrAlN-réteg kifejezetten rossz tapadású (az összehasonlító képsorozat szerint H5/H6 minősítésű), míg a TiAlN-bevonatok valamivel jobb tapadást mutatnak, H3/H4 minősítést kapnak a Daimler-Benz-teszt alapján, ahogyan azt az 5. ábrán láthatjuk.
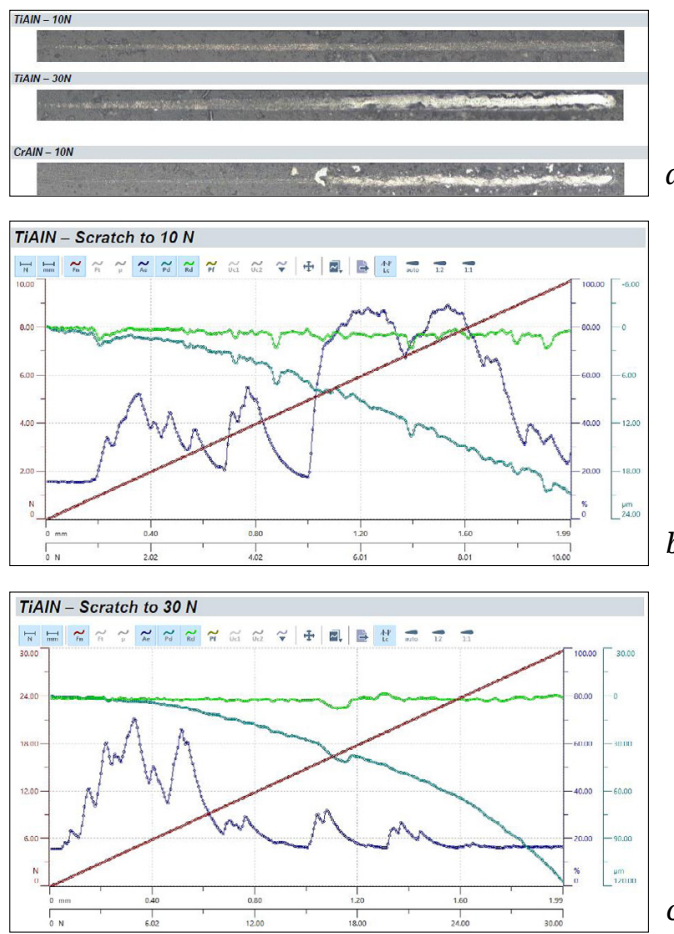

c)

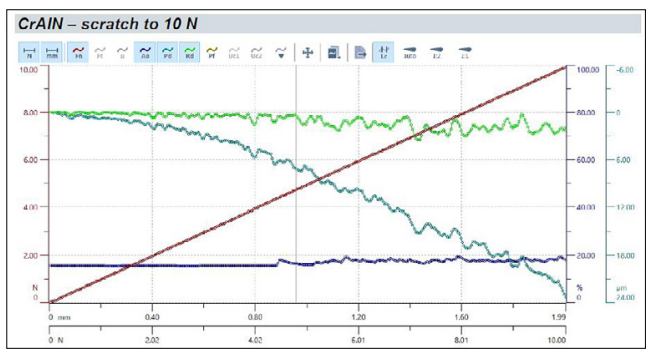

4. ábra. Karcteszt eredménye - CNMG 120408 jelü bevonatolt lapkáknál

a) A karcolások optikai megjelenése

b) $10 \mathrm{~N}$-os max. terhelés TiAlN-bevonat

c) $30 \mathrm{~N}$-os max. terhelés TiAlN-bevonat

d) $10 \mathrm{~N}$-os max. terhelés CrAlN-bevonat 

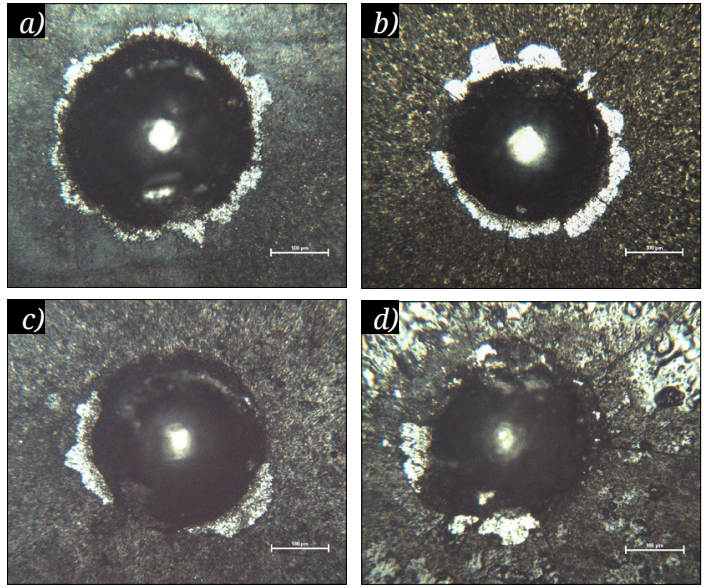

5. ábra. Daimler-Benz-teszt eredménye CNMG 120408 jelü bevonatolt lapkáknál

a) TiAlN-bevonat az 1. számú lapkán

b) TiAlN-bevonat a 2. számú lapkán

c) CrAlN-bevonat az 1. számú lapkán

d) CrAlN-bevonat a 2. számú lapkán

\section{Következtetések}

A tapadásvizsgálatok magyarázattal szolgáltak részben a forgácsolás közben bekövetkező relatív gyors bevonatlekopásra, függetlenül attól, hogy nedves vagy száraz körülmények közt történt-e a forgácsolás. A vizsgálatok szerint a porkohászati úton előállított relatív érdes felületű CNMG120408 típusú lapkákon a relatív vastag TiAlN-réteg mutat elfogadható minőségű tapadást, a CrAlN-réteg már kis erő hatására felszakad, a dinamikus Daimler-Benz-teszt szerint pedig kifejezetten rossz minősítést kaphat.

\section{Köszönetnyilvánítás}

A szerzők köszönetüket fejezik ki a munkájukhoz nyújtott anyagi támogatásért az EFOP-3.6.1-16-201600010. számú projekt keretében a magyar államnak és az Európai Uniónak.

\section{Szakirodalmi hivatkozások}

[1] Bitay E.: Bevonatolt gyorsacélok kopásállósága/ Coated HS Steels Wear Resistance. XVIII. FMTÜ, EME, Kolozsvár, Románia 2013, 73-76. https://doi.org/10.36243/fmtu-2013.10

[2] Kovács T. A., Umesh Mhatre, Nyikes Z., Bitay E.: Surface Modification Innovation for Wear Resistance Increasing. In: IOP Conf. Series: Materials Science and Engineering. vol. 613. (2019). 5th International Conference on Competitive Materials and Technology Processes 8-12 October 2018, Miskolc-Lillafüred, Hungary.

https://doi.org/10.1088/1757-899X/613/1/012039
[3] Fábián E. R, Furkó M., Vehoczki B.: Különböző típusú elektrokémiai bevonatok tulajdonságai. In: Fiatal Müszakiak Tudományos Ülésszaka, 19. (2014) 145-148.

https://doi.org/10.36243/fmtu-2014.029

[4] Kovács-Coskun T., Bitay E.: The hardness control in the coated surface layer. Materials Science Forum, 729. (2013) 415-418.

https://doi.org/10.4028/www.scientific.net/ MSF.729.415

[5] Bitay E., Kovács T.: The effect of the laser surface treatments on the wear resistance. Materials Science Forum, 649. (2010) 107-112.

https://doi.org/10.4028/www.scientific.net/ MSF.649.107

[6] Bitay E.: Lézeres felületkezelés és modellezés. Müszaki Tudományos Füzetek 4., EME, Kolozsvár, 2007. https://doi.org/10.36242/mtf-04

[7] Bagyinszky Gy., Bitay E.: Kopásálló felületkezelt rétegek minősítése/Characterization of surface treated, wear resistant layers. In: Fiatal Müszakiak Tudományos Ülésszaka, 14. (2009) 13-16. https://doi.org/10.36243/fmtu-2009.08

[8] Bitay E.: Lézeresen kezelt felületek kopásállósága. In: Fiatal Müszakiak Tudományos Ülésszaka, 6 . (2001) 111-118. https://doi.org/10.36243/fmtu-2001.23

[9] Sebestyén A., Nagyné Halász E., Bagyinszky Gy., Bitay E.: Felületmódosítási eljárások hatása acélok kopásállóságára. In: Fiatal Műszakiak Tudományos Ülésszaka, 12. (2007) 161-169.

https://doi.org/10.36243/fmtu-2007.4

[10] Liu Aihua, Deng Jianxin, Cui Haibing, Chen Yangyang, Zhao Jun: Friction and wear properties of TiN, TiAlN, AlTiN and CrAlN PVD nitride coatings, Int. Journal of Refractory Metals and Hard Materials, 31. (2012) 82-88.

[11] Tillmann W., Grisales D., Stangier D., Butzke T.: Tribomechanical behaviour of TiAlN and CrAlN coating deposited onto AISI H11 with different heat treatments. Coating, 9/519. (2019) 2-21.

[12] Rupetsov V, Minchev R.: Experimental calo tester for the coating thickness measurement. $15^{\text {th }}$ International Scientific Conference Smolyan, Bulgaria, 2016. 188-191.

[13] Tribotechnik: Kemény bevonati rétegek vastagságmérése Calo-teszttel

https://www.tribotechnic.com/en/products/ calotest/

[14] PVD-bevonatok vastagságmérése

https://www.pvd-coatings.co.uk/Ph.D.-coating-technology/testing-equipment/coating-thickness-tester

[15] Bevonatok tapadásvizsgálata karcteszteléssel https://www.anton-paar.com/corp-en/products/ details/micro-scratch-tester-mst3

[16] Verein-Deutscher-Ingenieure 1992 Daimler Benz Adhesion Test VDI 3198 (Dusseldorf: VDI-Verlag). 7. 